\title{
Primary School Teachers' Perceptions About Refugee Children Inclusion in Greek Schools: Are Teachers Prepared?
}

\author{
Evmorfia Kipouropoulou \\ University of Western Macedonia, Florina, Greece
}

\begin{abstract}
This research is mainly exploring primary school teachers' perceptions about refugee children inclusion in Greek schools. More specifically it focuses on how teachers construct their discourse while talking about refugee students and their intercultural competencies as agents of inclusion and social justice in the context of Inclusive Pedagogy. This paper focuses on two research aspects: teachers' discursive construction about refugee children, their inclusion in Greek educational system and the intercultural communicative competencies that teachers have acquired through their professional development. Teachers blame the government for not being prepared and for its incapacity to educate and train teachers. Therefore, they feel insecure to deal with the new educational multicultural environment and include refugee children in their classrooms, while they discuss the need to give refugee children equal educational opportunities. Twenty-five interviews were conducted and have been interpreted using Critical Discourse Analysis as used by Norman Fairclough, Robert Hodge, and Gunther Kress.
\end{abstract}

Keywords: inclusive education, intercultural education, teachers' professional identity, teaching and teachers' education, Critical Discourse Analysis

\section{Introduction}

During the years 2015-2016, Greece was faced with a rapid influx of refugees, who tried to flee war and poverty in their home countries in the Middle East and South Asia. These refugees are in search of a better, and safer, life for themselves and their families. The refugee population that arrived in our country is not homogenous.

The number of documented refugees in the country rises up to 58,$000 ; 16,000$ were moved in the region of Northern Macedonia Greece. 43\% come from Syria, 27\% from Iraq, 7\% from Afghanistan, 5\% from Turkey, $4 \%$ from Pakistan, and 2\% from Iran (UNHCR).

A great percentage of the refugee population having entered the country consists of people under the age of 18 (Hellenic Republic, General Secretariat for Media and Communication, 2017, pp. 2-3).

Over the Greek territory, the number of documented refugees is more than 60.00 including about 12.000 accommodated in reception centers in the islands (UNHCR (2018), Joint Agency Briefing Paper 2017: 8-9). The European Union, considering the facts as well as the Greek government's difficulty to deal with the crisis, proposed an educational program for the children of refugees, which referred to the academic year 2016-2017. The program was flexible and adjustable to the specific needs delineating the refugee crisis. The proposal was

Evmorfia Kipouropoulou, Ph.D. and Postdoc. in Education, Special Scientist, Department of Primary Education, University of Western Macedonia, Florina, Greece. 
based on the volatile nature of the refugee population, and on the management of refugee education through the cooperation of different agencies of the Ministry of Education, various other ministries, international and non-government organizations.

The above proposal by the European Union was accepted in June 2016 (Scientific Committee Ministry of Education and Religious Affairs, 2017, p. 33).

The First Reception Service can establish Reception Centers for the accommodation of asylum seekers or citizens of third countries belonging to vulnerable groups, such as unaccompanied minors, seniors, women during pregnancy, single-parent families with minors, victims of torture, etc. (Government Gazette, Issue A', Par. 2, Article 11 of Law 3907/2011, p. 25).

Apart from the documentation of the newly arrived population, immediate measures had to be taken for shelter, food, and the medical care of these refugees. The need for education was also urgent, considering the thousands of pre-school and school-age children among the newly arrived. Entrance and inclusion of the refugee children in Greek primary schools is an issue that troubled the Greek educational community to a great extent, following the school year 2016-2017, during which the first ministerial decrees were issued, and actions on refugee education were taken.

The plan for the refugee children's inclusion in education comprises of two important initiatives: The creation of Reception and Hospitality Facilities for Refugee Education and the establishment of the role of Coordinator for Refugee Education in the Refugee Reception Centers.

The Ministry of Education and Religious Affairs tends to the education of all the groups of minors. Within the Reception Centers for Refugee Education (Government Gazette, Issue A' 159, Art. 38 of Law 3315/2016, p. 8436), a weekly educational schedule of 20 hours (four hours per day) has been developed for children aged 6-12 years (primary school), given below:

Table 1

Timetable

\begin{tabular}{ll}
\hline Teaching subject & hours \\
\hline Greek language & 6 \\
English language & 4 \\
Mathematics & 3 \\
Physical education & 3 \\
New technologies & 2 \\
Art & 2 \\
\hline
\end{tabular}

A question that arises and forms the research context:

How far the country's educational system and policy provides equal opportunities for everyone in the framework of the Education for Inclusion, support for the children of refugees, and the creation of a positive atmosphere of acceptance which will reinforce the student's integration in school activities, their socialization, as well as mutual acceptance?

\section{Theoretical Framework}

\section{Inclusive Pedagogy}

The needs of today's school system - and more specifically in Greece, a country faced with the economic crisis, but also one that has received a small portion, compared to international numbers, of the huge refugee 
crisis - constitute the inclusive approach a one-way street in education. Inclusion is not related to assimilation, and consists of two dimensions, the social and the pedagogical. The social, as well as the educational, aim is for all students without exception, even those considered different, to be treated as equal members of the educational community. The value that the Education of Inclusion promotes is the procurement of equal opportunity for all students, as well as the acceptance and respect of the equality and difference among all children/students. No child can be considered "unable to be educated" in the classroom (Choleva, 2017).

The term "inclusion" is contemporary but subsequent to the concepts of "assimilation" and "integration" and refers to the ways in which a student can fit in a school environment. Inclusion takes into consideration the conditions under which the education of the students takes place, that is, the efforts that are made by a school for the educational needs of all students to be met, without exclusion and discrimination. The schools', and the general educational systems', duty to adjust in order to accept all children without exception and exclusion, responding to their educational needs, is underpinned.

The definitions proposed regarding the education of inclusion focus "on the provision for equal opportunity, interaction, and the procedures followed for its realization, as well as on the institutional, organizational and functional aspect". This concerns a new philosophy of change for the entirety of the processes of today's school, which involves reform concerning all students and aims at their inclusion (Stasinos, 2013; Evagelou \& Moula, 2016, p. 157).

What interests a modern Pedagogy of Inclusion is the expansion of what is usually available to the class community. This is based on the shift of educational thought from an approach that works for the majority of the students who exist besides (a few) "different" students facing problems, toward one that includes equal opportunity for learning, sufficient for, and available to, everyone, so that all students can participate in the life of the classroom (Florian \& Hawkings, 2011, p. 826; Pantic \& Florian, 2015).

Over the last decades, the Pedagogy of Inclusion is an important issue for the educational programme of most countries, so that they can meet the needs of different educational groups, at European, as well as international, level. Twenty first century education must aim at the integrity, acceptance, respect, and wellbeing of the individual in relation to others.

For inclusive education to be successful, not only strategies and specific teaching methods are necessary, but the perceptions, stance, and pedagogy need to radically change, so that all students have an equal opportunity in learning. It is worth noting that Inclusion comes with a social dimension - it does not only aim at academic growth, but also on the student's social development, by encouraging the equal participation in the social becoming (Mamas, 2014, p. 81-83).

It is not only required of the teacher to have the appropriate knowledge on teaching techniques and psycho-pedagogical interventions, or a positive attitude toward difference. There has to be the will for self-improvement and continuing opportunities for professional development in the field, so that the teacher improves on his or her intercultural skills. These skills relate to the experience of a communicative relation to the diverse students and the complete acceptance of difference through practical procedures. This comes with experience and a deep knowledge of dealing with multiculturalism, which can be acquired through experiential situations and practices, by which the teacher improves his or her behavior toward different students (Kiridis \& Andreou, 2005, p. 239; Perry \& Southwell, 2011).

Research shows that different teachers perceive and allot different meanings to the coexistence of students coming from various countries in the school environment, while they express opposing views (Pickert \& Chock, 
1997, pp. 18-19). On the one hand, some teachers claim that multiculturalism comes with lower academic performance by non-native students. On the contrary, there are many teachers who revert to the positive aspects of multiculturalism - they claim that difference disperses prejudices and hostility and helps the development of altruism and the reduction of insecurity. These teachers believe that multiculturalism offers them the opportunity to see themselves on the faces of their different students, and challenges them to try and include these students in the educational environment. It is worth noting that this category of teachers promotes the cultural exchange among the Greek and foreign students. According to research on teachers' perceptions, the culturally other is seen as both positive and negative by different teachers since, on the one hand, some claim that difference is positive and creative, while a number of teachers see a negative social situation in such difference. It is also found that highly qualified teachers, who are either trained on issues of intercultural education, or with more years of service, experience of non-native students in the classroom and competence in a foreign language, see and rather handle foreign students, and issues of bilingualism and bilingual education, through a more intercultural perspective (Lampros \& Nikolaou, 2014, p. 387).

In one of their studies, Leighton and Harkings (2010) claim that primary school teachers have better cultural skills than those in secondary education. Teachers with more years of experience show better results when it comes to their skills but fall short in their skills regarding the knowledge of interculturalism in relation to their younger colleagues. Teachers, who have been thus trained or have taken part in workshops, show higher levels of intercultural competence. Spinthourakis' studies reveal similar results (2007). According to her research, it is shown that student-teachers, who have been active participants in an interactive environment and who have been informed and trained through different programs, have also changed the way they perceive issues of identity and different.

A study by Bougioukli (2014) on the role of teachers' intercultural preparedness in the promotion of a psychologically positive intercultural environment reveals that as far as the different dimensions of this positive environment are concerned, some factors of intercultural preparedness are determining. These factors are the stock of knowledge and education the teacher must possess, as well as the ability to put theory into practice, so that he or she can choose among the appropriate strategies and methods in order to teach in the intercultural classroom. This study poses the need for the improvement of the interculturally prepared teacher's profile and so also of the psychologically positive environment that he or she creates for the students.

With a few exceptions, the findings of Aslanidou and Derri's research (2013), regarding the stance, knowledge, and practices of teachers and physical education trainers in relation to intercultural pedagogy and teaching, seem to be disheartening, as they reveal the teachers' prejudice, which stems from the lack of relevant training as well as from the teachers' inability to divest themselves of their perceptions and to understand and accept cultural diversity.

\section{Research}

The present research studies primary school teachers' discourse — as well as the factors that positively or negatively influence them —on the inclusion of refugee children in the Greek school system.

Throughout the study we investigate:

(A) Teachers' discourse concerning the integration of refugee children in Greek school and,

(B) Teachers' discourse concerning their professional and intercultural skills.

The main research questions were the following ones: 
- Which are teachers' perceptions about the inclusion of refugee children in Greek schools?

- How far teachers are ready to respond to new challenges?

For the purposes of this paper, we study teachers' discourse concerning the main research question that refers to the integration of refugee children in Greek school.

The material for the study comprises of the discourse of 25 teachers through semi-structured interviews (18 women; 7 men), which was gathered through the method of convenience sampling. ${ }^{1}$

Five of them have had training or post-graduate studies in Intercultural Education. The analysis was conducted using the methodological approach of Critical Discourse Analysis as it is studied by Norman Fairclough $(1989 ; 1992 ; 1995)$ and Gunther Kress $(1988 ; 1989)$ which is based on a cultural theory of discourse under the epistemological context of social constructionism. Therefore, discourse is formed, but also limited, by social factors such as class, class systems, institutions, norms and social conventions and constructs social positions, subject positions for the social subjects and the images of the self, as much as social relations, facilitating the construction of systems of knowledge and belief (Fairclough, 1992, pp. 62-65).

The discursive practice is a particular form of social practice. Analysis of a discourse as a piece of discursive practice focuses upon processes of text production, distribution, and consumption. During the phase of description, text analysis comprises of lexis, grammar, metaphor, lexicalization, the coherence of argumentation and inter-textuality. In the analysis of the linguistic practice, coherence and intertextuality is also used. In interpretation the concept of the context is used, which includes what is known as situational context. In this case, the situational context is constituted of the 25 interviews that were conducted at school. The interpreters conclude on certain interpretations for the entirety of the social and discursive practices.

Description, the process that is related to text analysis, and the analysis of the linguistic and social practice, were employed, along interpretation by which we search for the relationship between interaction and the social situation on the one hand and the social definition of the production and interpretation of discourse on the other. Basic elements of analysis were used, such as intertextuality, discourse representation, modality, metaphor, cohesion, nominalization, and naturalization (Fairclough, 1992, pp. 71, 75-77).

Due to the limitations of the technical guidelines of the present paper, the analysis and interpretation of teachers' discourse is paradigmatic.

\section{Research Results}

\section{Integration of Refugee Children in School}

Most of teachers express a positive point of view about refugee children inclusion. They develop their utterances with high modality, expressing their opinions with certainty. They consider cultural pluralism to have a positive influence on the socialization of all students and their interaction to positively affect the acceptance of difference.

"It's better if they are integrated in the classroom. It's better than we create ghettoes" (man).

"It goes without saying that these children should be integrated...I don't understand why we make a big deal out of it" (woman).

\footnotetext{
${ }^{1}$ I would like to thank my postgraduated students (Basiliki Gavriil, Dimitris Bogdanos, Eleni Kampouri, Giorgos Mantsos, Evaggelia Margariti, Antonia Markou, Vasiliki Notopoulou, Evgenia Pahi, Kiriaki Piritzaous, Despina Sozeridou, Giorgos Tavellaris, Maria Theohari, Giorgos Tsotsos, Evdokia Vasiliadou) who helped me gather the research material and conduct this research.
} 
"Basically (refugee) students should not be educated in separate facilities, but within public schools. This will improve their self-respect, and all will benefit from their contact with refugee children. It is very important for a climate of solidarity and respect to be created" (woman).

"The right thing to do is to integrate (the students) in the Greek reality, as it is unfair to these people, who have been deprived of so many things, if we-a supposedly free country, deny these to them as well" (woman).

We can see the dominant use of the third person in the references to the refugee communities, as they distance themselves through their discourse. Less are the uses of the first person in combination with metaphors, which denotes a sentimental tone: The teachers speak as collective subjects.

"I believe it is good for reception classes to exist, so that refugee children can attend while the rest of the students follow their basic courses, and the secondary ones can be done in common, so the refugee children's integration is facilitated. However, this shouldn't have a negative impact on the ...eh...the progress of the rest of the students" (woman).

"I believe they should definitely be integrated as this will help Greek children to be more tolerant of difference. I think that Greek children, too, will be helped by this integration" (woman).

Teachers construct their utterances with strong modality, expressing with certainty their opinion on the necessary integration of refugee children in school but also the necessity for their socialization in the new environment, by placing emphatic adverbs and expressions at the beginning of their utterances "basically, the right thing to do, it goes without saying, definitely", and by using the Declarative. What is more, they consider cultural pluralism and the students' interaction to have a positive effect on their socialization as well as on their acceptance of difference. It is interesting to note that the teachers distance themselves by primarily using the third person in their references to the refugee communities and the need for those children's integration in the classroom. On fewer occasions, we witness the use of the first person along a metaphorical use of the language, which gives it a sentimental tone, where the country's and the school system's duty to accept refugee children is referred. Thus, the teachers express themselves as collective subjects, "to deny them, it's better than if we create ghettoes, I don't understand why we make a big deal out of it, according to me these people have suffered". Teachers revert, in their discourse, to concepts from the scope of intercultural education and the Pedagogy of Inclusion. They talk about "solidarity, respect, improvement of the student's self-image, integration, justice, democratic concepts, avoidance of ghettoes".

One female teacher refers to integration classes already existent in schools, by proposing the "basic" courses to be done in them while the rest of the courses would be done in the regular classroom - alluding to the function of intercultural schools. However, she expresses her concern and reluctance regarding the progress of the other students: "This shouldn't have a negative impact on the ...eh...the progress of the rest of the students".

Another female colleague seems to promote only the benefit of the Greek students, by emphatically referring to the relevant national identity: "Because this will help Greek children to be more tolerant of difference. I think that Greek children, too, will be helped".

\section{Reluctant Voices}

Some voices seem opposing and reluctant. Quite a few teachers express themselves with skepticism toward Reception Facilities for refugees, as well as toward the school systems and their own preparedness to receive refugee students, by starting their discourse with negative utterances as a basic form of modality 
(Hodge \& Kress, 1993, pp. 145-146), while they reject any positive references to the refugee students' integration:

“I don't know, probably, it can't be done, they don't want to, the conditions are no better, there is no infrastructure, not immunized children, I think there is no infrastructure, I find it harder to do, the refugee community is tough".

"In Greece, we generally find it harder to accept difference. Certainly, Greek students' parents will react, as has already happened in many other cases. They do not want refugee children as they are not immunized and the sanitation conditions they live in are not the best" (woman).

By reproducing the dominant stereotypical representation of public discourse regarding the non-immunized refugee children, she claims with certainty, and by generalization, that "in Greece we do not accept difference", speaking as a collective national subject. The high modality with which she ascertains her discourse is characteristic, either with the use of the extreme "generally", or with the use of the Declarative and the emphatic adverb "certainly".

"I don't know. They carry their own stock of values and customs, mentality, and sometimes the refugee community is harsh" (man).

"Being a teacher is, probably, the last role to play-teachers are called upon to be child therapists, nurses, electricians, parents' consultants - it's very demanding, there is no respect left any more. Society has devalued the role of the teacher, and now they cannot be called upon to respond to additional demands... asking them, for example, to include the refugee children" (man).

Using non-conjunctional propositions, the teacher enumerates — slightly ironically - the many roles of the teacher and emphatically refers to the professional identity being devalued by the impersonal collective "society", which is emphatically repeated twice. The teacher's devalued identity seems to be further burdened by the additional demand to integrate refugee students "for example, to include the refugee children".

\section{The Absence of Organization, Planning and Training as Reasons for a Sense of Insecure Identity}

Many of them refer to the lack of infrastructure and teacher training on issues of intercultural education, but also to teachers' willingness to engage in the pedagogical practices for the integration of refugee children.

"I believe that, if the ministry takes measures in order to train teachers, and if there is the appropriate briefing of the Greek students' parents, certain fears will be overcome" (woman).

"My involvement would be more effective if I had adequate preparation and training, and the right conditions at my workplace" (man).

"I believe there is no infrastructure to support the children's integration in the Greek schools, there is no serious infrastructure. Everything is done, I think, based on the teacher's diligence" (woman).

"You have to know the subject. Since I don't know it, I don't know what role it plays, the infrastructure. It's not something that we can, just, take responsibility for" (man).

"I do not find integration negative, as long as there are the right conditions, infrastructure, and institutions" (male teacher).

Characteristic is the use of the conditionals in the teachers' utterances, through which they present the conditions for an effective teaching to refugee children. These conditions relate mostly to infrastructure and the training programs for which the state, and not themselves, should be responsible. Thus, they use the third 
person in their utterances, as well as several nominalizations: lack of infrastructure, teacher training on issues of intercultural education, the integration of refugee children, adequate preparation and training etc. The teachers' willingness and the subject's knowledge are also mentioned once in each discourse.

\section{Discussion}

Most participants express themselves positively concerning the influence of multi-culturalism. Teachers' discourse is often revealed as reluctant and insecure about their competence and especially their intercultural competencies, even if most of the participants have more than 10 years of teaching experience. However, it should be noted that the teachers have not had any kind of relevant training, nor have they acquired a relevant post-graduate degree. Two female teachers are the exception —one attended classes on intercultural education during her under-graduate studies, and the other was currently studying at post-graduate level. Both expressed themselves with positive utterances regarding the integration of refugee children in school without pre-requisites. There were other teachers within the sample who expressed similar views, without having had any relevant academic background.

As far as the contradictory discourses that have been developed, the results of the present study are similar to those drawn by other studies that also underline how teachers conceptualize the co-existence of students coming in the classroom from diverse countries in different ways (Pickert \& Chock, 1997), while they also express opposing views. In the present study, there seems to be no willingness from the part of the teachers to teach in multicultural classrooms - as in one relevant study by Bougioukli (2014) - however, there seems to be a need for the improvement of the interculturally-prepared teacher's profile, as well as of the psychological environment that he or she creates for the students. It is imperative for teacher training initiatives to be taken on intercultural subjects, especially for the teachers in the region of North-Western Macedonia in Greece, so that they begin to formulate their intercultural competencies and an awareness and sensitivity regarding issues of Intercultural Education and the Pedagogy of Inclusion.

Several teachers refer to the lack of infrastructure and appropriate teacher training on issues of intercultural education.

It is also found that teachers are generally not familiar with issues of intercultural education and do not know about projects by either social institutions, universities, Non Governmental Organizations, or even by the government relevant to reception and accommodation facilities for refugees, their function and operation. It should be noted that in the specific geographic region of Northwestern Macedonia of Greece there had not been, until very recently and not in the city of Florina in Greece, any Refugee Reception Centers.

Over the last decades, Inclusive Education has been of critical importance for most countries' programs and planning. Twenty first century education needs to aim at dignity, acceptance, respect, and the good living conditions of all people.

The results of the present study, albeit a work in progress, shed light on the views of active teachers and press for the necessity of improving the profile of the inter-culturally sensitive teacher. They also underpin the need for training teachers in matters of intercultural education, while posing questions for further investigation.

\section{References}

Aslanidou, M., \& Deri, B. (2013). Stances, knowledge and practices of teachers and physical education teachers relating to difference and cultural pedagogy and education. Investigations in Physical Education \& Sports, 11(1), 8-19. 
Bennett, M. J. (1998). Intercultural communication: A current perspective. In M. J. Bennett (Ed.), Basic concepts of intercultural communication: Selected readings (pp. 1-34). Yarmouth, ME: Intercultural Press.

Bougioukli, P. (2014). The role of teachers' intercultural preparedness in the promotion of a positive psychological climate in multicultural environments (Thesis, University of Macedonia. Department of Educational and Social Policy. Post-Graduate Program on Life-Long Education. Retrieved from https://dspace.lib.uom.gr/handle/2159/16260 (2-5-2018)

Choleva, A. (2017). What if it were you? A sensitization program on human rights and refugee-related issues, with interactive, experiential activities, theatre techniques and educational drama. Theory and Practice in Pedagogical and Educational Sciences, 3, 142-156. Retrieved from doi:http://dx.doi.org/10.12681/dial.15208

Evagelou, O., \& Moula, E. (2016). Comparative study of intercultural and inclusive education. Erkina, Investigation of Educational and Scientific Subjects, (10), 155-165.

Fairclough, N. (1989). Language and power. London: Longman.

Fairclough, N. (1992). Discourse and social change. Cambridge: Polity Press.

Fairclough, N. (1995). Critical discourse analysis. London: Longman.

Florian, L., \& Black-Hawkins, K. (2011). Exploring inclusive education. British Educational Research Journal, 37, 813-828.

$\begin{array}{llll}\text { Government } & \text { Gazette } & \text { Retrieved } & \text { from }\end{array}$ https://www.minedu.gov.gr/publications/docs2016/\%CE\%96\%CE\%95\%CE\%A0.pdf

Hellenic Republic, General Secretariat for Media and Communication. (2017). Refugee crisis. Fact sheet. Retrieved from https://government.gov.gr/wpcontent/uploads/2017/04/gr_fact_sheet_refugee_print_19_01_2017-2.pdf (28/04/2018)

Hodge, R., \& Kress, G. (1993). Language as ideology. London: Routledge.

Joint Agency Briefing Paper. (2017). Information retrieved from https://reliefweb.int/sites/reliefweb.int/files/resources/greece_roadmap_oxfam_final.pdf

Kiridis, A., \& Andreou, A. (2005). The transformations of otherness: From class to cultural diversity: The two sides of the same coin. In A. Andreou and A. Kiridis (Eds.), Aspects of otherness, 9-17. Athens: Gutenberg.

Kress, G. (1988). Communication and Culture. Sydney: University of New South Wales Press.

Kress, G. (1989). Linguistic processes in sociocultural practice. Oxford: Oxford University Press.

Lampros, I., \& Nikolaou, G. (2014). Do the mother tongues of foreign-language-speaking students have a place in the Greek primary school? Teachers' opinions. In Research in Sociology of Education Conference Proceedings (pp. 379-389). University of Ioannina \& Hellenic Sociological Society.

Law 3907/2011 Establishment of an Asylum Service and a First Reception Service, adaptation of the Greek legislation to the provisions of the Directive 2008/115/G.G (OR EC?) "with regard to the common rules and procedures in Member States for the return of illegally staying third-country nationals" and other provisions. (2011). Retrieved from http://asylo.gov.gr/wp-content/uploads/2014/06/3907.pdf (11/04/2018)

Leighton, L., \& Harkins, M. (2010). Teachers perceptions of their cultural competencies: An investigation into the relationships among teacher characteristics and cultural competence. The Journal of Multiculturalism in Education, 6(2), 1-28.

Mamas, H. (2014). "Inclusive and Intercultural Education: two sides of the same coin?" in Hatzisotiriou \& Xenofontos ed. Intercultural Education, Challenges, Aspects and Suggestions,Saita: Kavala, Greece: 80-96.

Pantic, N., \& Florian, L. (2015). Developing teachers as agents of inclusion and social justice. Education Inquiry, 6(3), 333-351.

Perry, L. B., \& Southwell, L. (2011). Developing intercultural understanding and skills: Models and approaches. Intercultural Education, 22(6), 453-466.

Pickert, S., \& Chock, P. P. (1997). The concept of culture in multicultural education: Views of teacher educators in the USA. ERIC Data Base. Retrieved from www.erid.ed.gov (19/08/2006, ED437394)

Scientific Committee for the Support of Refugee Children. (2017). The work of refugee education. Retrieved from https://www.minedu.gov.gr/publications/docs2017/16_06_17_Epistimoniki_Epitropi_Prosfygon_YPPETH_Apotimisi_Prota seis_2016_2017_Final.pdf $(22 / 04 / 2018)$

Spinthourakis, A. (2007). Recognizing and working with multiculturalism: A reflective analysis of a university multicultural education course. The Journal of Learning, 14(5), 67-74.

Stasinos, D. (2013). Special-needs education 2020. Toward an inclusive or holistic education in the new digital school with digital champions. Athens: Papazisis Publications.

UNHCR. (2018). Introduction page. Information retrieved from https://www.unhcr.org/greece.html 